\title{
Heat Transfer Enhancement of Laminar Flow in a Circular Tube Using Swirl/Vortex Generator
}

\author{
(Peningkatan Pemindahan Haba Aliran Lamina di dalam Tabung Membulat \\ Menggunakan Penjana Swirl/Vorteks) \\ Sami D. Salman*, Abdul Amir H. Kadhum, Mohd S. Takriff \& Abu Bakar Mohamad
}

\begin{abstract}
Swirl/vortex flow generator is an important form of passive augmentation techniques consist of a variety of tube inserts, geometrically varied flow arrangements and duct geometry modifications that produce flows. Twisted-tape is one of the most important members of this form which used extensively in different type heat exchangers. This paper presents a research on heat transfer enhancement and friction factor characteristics in a circular tube using CFD simulation. Plain twisted tape inserts with twist ratios $(y=2.93,3.91)$ and slant baffled twisted tape inserts with baffle angle $30^{\circ}$ and twist ratio $(y$ $=2.93$ ) have been used for the simulation. The results obtained by simulation matched with the literature correlations for plain tube with the discrepancy of less than $\pm 8 \%$ for Nusselt number and $\pm 6.25 \%$ for friction factor. The results have also revealed that the heat transfer in term of the Nusselt number enhanced with increases of Reynolds number, decreases of twist ratio. Among the various twist ratios, the slant baffled twisted tape with twist ratio of $y=2.93$ has offered a maximum heat transfer enhancement with significant friction factor.
\end{abstract}

Keywords: Heat transfer augmentation; baffled twisted tape insert (BTT); FLUENT; CFD simulation

ABSTRAK

Penjana aliran Swirl/vorteks adalah satu bentuk teknik pembesaran pasif penting yang terdiri daripada pelbagai penyelitan tiub, pengaturan aliran geometri pelbagai dan pengubahsuaian saluran geometri yang menghasilkan aliran. Pita-terpiuh adalah salah satu daripada kaedah bentuk ini yang paling penting yang digunakan secara meluas dalam pelbagai jenis penukar haba. Kertas ini membentangkan penyelidikan mengenai peningkatan pemindahan haba dan ciri-ciri faktor geseran di dalam tabung membulat menggunakan simulasi CFD. Pita terpiuh penyelitan biasa dengan nisbah piuh $(y=2.93,3.91)$ dan pita terpiuh penyelitan bersesekat condong dengan sudut sesekat $30^{\circ}$ dan nisbah piuh $(y=2.93)$ telah digunakan untuk penyelakuan. Keputusan yang diperolehi dari simulasi dipadankan dengan korelasi literatur untuk tiub biasa dengan percanggahan kurang daripada $\pm 8 \%$ untuk nombor Nusselt dan $\pm 6.25 \%$ bagi faktor geseran. Keputusan juga telah menunjukkan bahawa pemindahan haba dari segi nombor Nusselt dipertingkatkan dengan peningkatan nombor Reynolds, berkurangan dengan nisbah piuh. Antara pelbagai nisbah piuh, pita terpiuh berseseket condong dengan nisbah piuh $y=2.93$ telah menawarkan peningkatan pemindahan haba maksimum dengan faktor geseran yang ketara.

Kata kunci: Pembesaran pemindahan haba; pita terpiuh penyelitan bersesekat condong (BTT); FLUENT; penyelakuan $C F D$

\section{INTRODUCTION}

The performance of conventional heat exchanger can be substantially improved by a number of enhancement techniques. These techniques are classified broadly as passive or active techniques. The active technique requires an external power facilitate the desired flow modification such as electrostatic field, surface or liquid vibration, etc. Whereas, the passive technique does not require any external energy. It requires fluid additives, special surface geometries or swirl flow devices i.e. twisted tape inserts. Numerous of experimental works on heat transfer augmentation studies using twisted tape have been reported in the literature
(Ujhidy et al. 2003; Ibrahim 2011; Jaisankar et al. 2009; Guo et al. 2011; Wongcharee and Eiamsa-ard 2011).

However, delimited literatures are available in CFD modeling of heat transfer using twisted tape inserts. Pathipakka and Sivashanmugam (2010) proposed CFD simulation of heat transfer and friction factor characteristics of the circular tube fitted with a right-left helical twist insert with $100 \mathrm{~mm}$ spacer based on experimental work. The simulated results of Nusselt number and friction factor were compared with the experimental data with good agreement. Shabanian et al. (2011) conducted an experimental and CFD modeling on at transfer and friction factor characteristics in air cooled heat exchanger using butterfly twist tape insert to 
investigate the effect of insert configuration on the Nusselt number, friction factor and thermal performance factor.

Salman et al. (2013) reports the application of a mathematical model of the heat transfer enhancement and friction factor characteristics of water in constant heatfluxed tube fitted with classical and elliptical cut twisted tape inserts using FLUENT version 6.3.26. The results show that the elliptical cut twisted tape with twist ratio offered higher heat transfer rate with significant increases in friction factor. Salman et al. (2013) numerically investigated the heat transfer of water in constant heat-fluxed tube fitted with classical and V-Cut twisted tape inserts using FLUENT version 6.3.26 and in a uniformly heated circular tube fitted with V-cut twisted tape inserts in laminar flow using FLUENT version 6.3.26. The results also reveal that the $\mathrm{V}$-cut twisted tape generated a maximum heat transfer rate with significant increases in friction factor, as compared with classical twisted tape.

This paper is to present numerical study on the heat transfer rate and friction factor characteristics in a round tube fitted with slant baffled twisted tape (SBT) insert based on an experimental data from Pathipakka and Sivashanmugam (2010). Liquid water was employed as the test fluid for the Reynolds number range of 200 to 2300 . Moreover, the plain twisted tape insert was also conducted for comparison. The longer term objective of this paper is to reveal that the insert configuration can play an important role on heat augmentation.

\section{MATERIALS AND METHODS}

PHYSICAL MODELS

The geometry and the grid of Slant baffled twisted tape insert (SBT) with a relative twist ratio, $y=2.93$ is depicted in Figure 1 and Figure 2. The material of construction of the tube and twisted tape is steel and aluminium, respectively. Water is selected as the working fluid and the thermo-physical properties of fluid are selected at $298 \mathrm{~K}$ and assumed to be temperature independent.

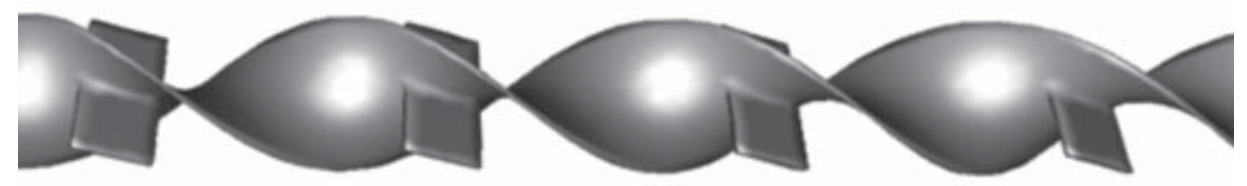

FIGURE 1. Slant baffled twisted tape insert

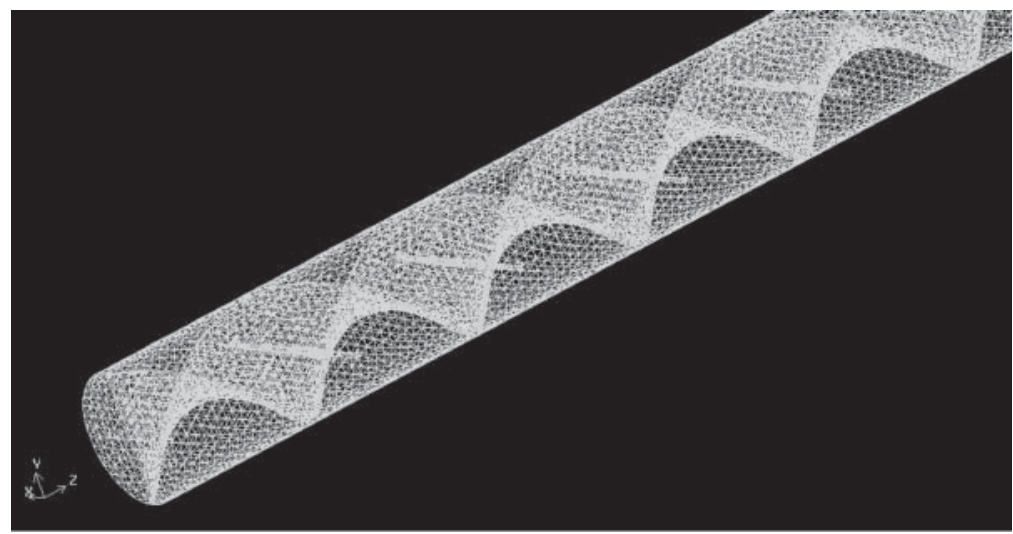

FIGURE 2. Grid for SBT inserts

MODELLING PARAMETERS AND NUMERICAL METHOD

Experimental data mentioned in Pathipakka and Sivashanmugam (2010) with the commercial software FLUENT 6.3.26 was chosen as the CFD tool to solve governing equations. Three dimensional steady state laminar flow through the tube fitted with baffled twisted tape inserts under constant heat flux is investigated by the following model equations.
Continuity equation for an incompressible fluid.

$$
\frac{\partial p}{\partial t}+\nabla \cdot(\rho \vec{v})=S_{m}
$$

Conservation of momentum.

$$
\frac{\partial v}{\partial t}+\rho(\vec{v} . \nabla) \vec{v}=-\nabla p+\rho \bar{g}+\nabla \cdot \tau_{i j}+\vec{F}
$$


Conservation of energy.

$\rho \frac{\partial}{\partial t}(\rho E)+\nabla \cdot\{\vec{v}(\rho E+\rho)\}=\nabla \cdot\left\{K_{e f f} \nabla T-\Sigma h_{i}\left(\vec{\tau}_{\text {eff }} \cdot \vec{v}\right)\right\}+S_{h}$

In the equations, $E$ is the energy component in energy equation, $F$ is the force component in momentum equation (N), $f$ the Fanning friction factor, $g$ is the acceleration due to gravity, $k_{\text {eff }}$ is the thermal conductivity in energy equation $(\mathrm{W} / \mathrm{m} \mathrm{K}), m$ is the mass flow rate of fluid $(\mathrm{kg} / \mathrm{s}), p$ is the pressure component in momentum equation $\left(\mathrm{N} / \mathrm{m}^{2}\right), S_{m}$ is the accumulation of mass $(\mathrm{kg})$ and $S_{h}$ is the accumulation of energy ( $\mathrm{J}) . \mathrm{T}$ is the temperature $\left({ }^{\circ} \mathrm{C}\right), v$ is the velocity component in momentum equation $(\mathrm{m} / \mathrm{s}), y$ is the twist ratio (length of one twist $\left(360^{\circ}\right) /$ diameter of the twist, $\rho$ is the density component in governing equations and $\vec{\tau}_{\text {eff }}$ is the stress component in momentum equation $\left(\mathrm{N} / \mathrm{m}^{2}\right)$.

\section{RESULT AND DISCUSSION}

GRID INDEPENDENCE TEST

A grid independence test was used to evaluate the effects of grid sizes on the simulated results. Three mesh volumes for Reynolds number, $R e=2000$ were considered in this test which is 692973, 775152 and 813865. It is observed that all the mesh volume has similar results of the Nusselt number with a percentage error up to $0.3 \%$. The higher number of mesh will consume more time to compute. Hence, the domain with meshed volume of 775152 was chosen to reduce the computational time.

\section{VALIDATION OF PLAIN TUBE SIMULATION RESULTS}

The results obtained by simulation are validated using plain tube correlations developed by Sieder and Tate (1936). The simulated data of the Nusselt number for a tube are compared with these correlations as illustrated in Figures 3 and 4. The results reasonably agreed well with the available correlations

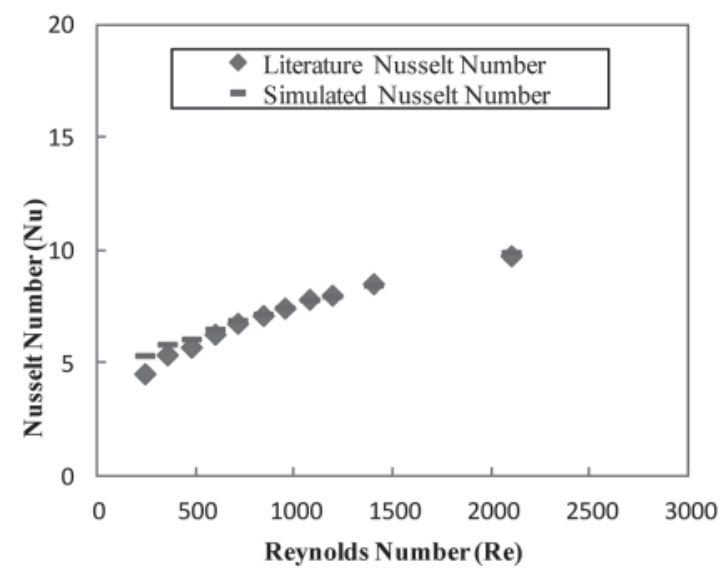

FIGURE 3. Plain tube simulated Nusselt Number vs Literature data within $\pm 8 \%$ and $\pm 10 \%$ for Nusselt number and friction factor respectively. Litureture data is from Pathipakka and Sivashanmugam (2010).

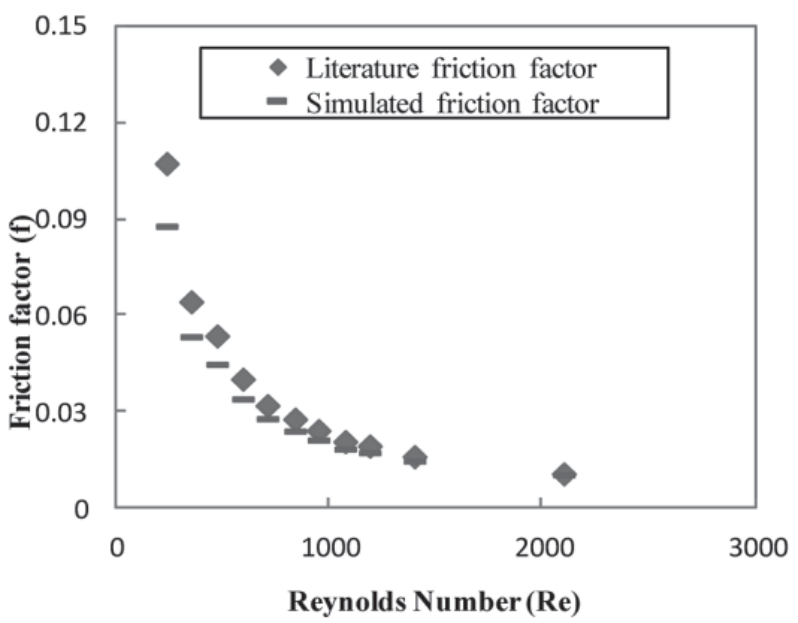

FIGURE 4. Plain tube simulated friction factor vs Literature data

EFFECT OF TWIST RATIO ON HEAT TRANSFER AND FRICTION FACTOR

Simulated data of the Nusselt numbers, friction factor and their variation with a Reynolds number of plain twisted tape inserts with twist ratio ( $y=2.93$ and 3.91) are shown in Figure 5 and Figure 6. For all range of the Reynolds number, it is clearly noted that the Nusselt number and friction factor increases with the decreases of twist ratio and the minimum twist ratio of $y=2.93$ offeres higher Nusselt number and friction factor than that of twist ratio of $y=3.91$. This implies that the minimum twist ratio $(y=2.93)$ generates stronger swirl flow with longer fluid flow path and better fluid mixing, resulting in a thinner thermal boundary layer along the tube surface and thus enhance the convective heat transfer. Furthermore, the lower twist ratio offers higher tangential

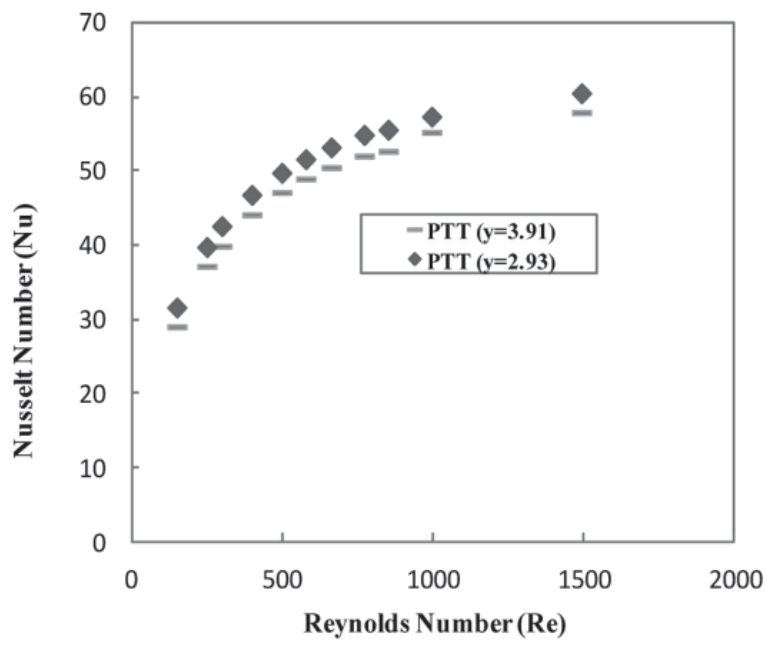

FIGURE 5. Simulated Nusselt Number for PTT with $(y=2.93$ and 3.91) 


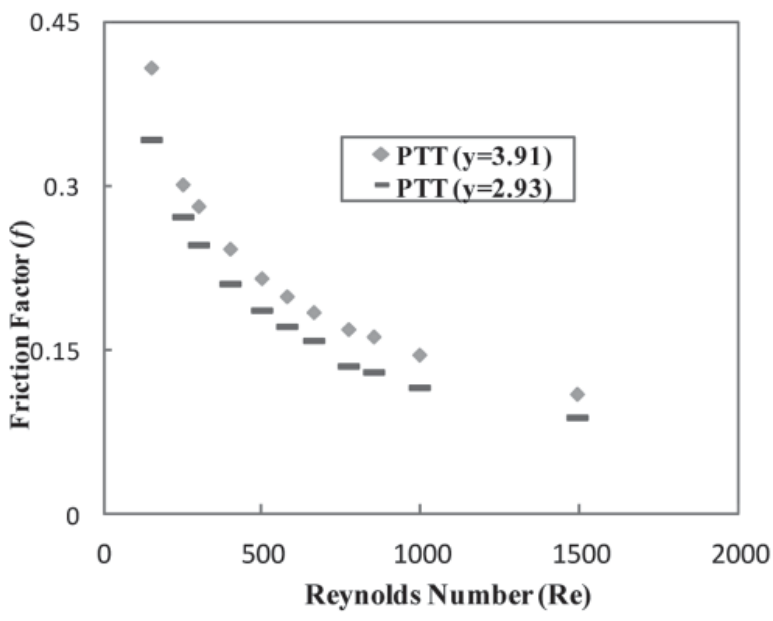

FIGURE 6. Simulated Fraction Factor for PTT with $(y=2.93$ and 3.91)

contact between the swirling flow and the tube surface, thus significant increases in friction factor is noted.

\section{EFFECT OF TWIST TAPE CONFIGURATION ON HEAT TRANSFER AND FRICTION FACTOR}

Simulated data for the Nusselt numbers, friction factor and their variation with Reynolds number for Baffled twisted tape insert (BTT) with twist ratio $y=2.93$ are shown in Figure 7 and Figure 8. For all simulated data, it is clearly noted that the Nusselt number and the friction factor in the tube fitted with a baffled twisted tape of $(y=2.93)$ and baffle angle $\left(\beta=30^{\circ}\right)$ is higher than the plain twisted tape. This means that the baffled twisted tape provides an additional turbulence to the fluid near the tube wall and behind the baffle configuration.

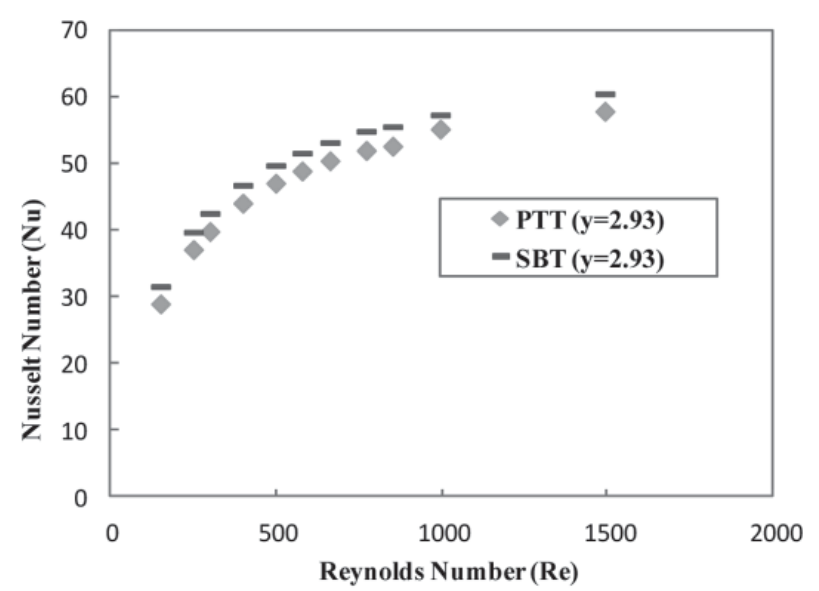

FIGURE 7. Simulated Nusselt Number for PTT and SBT

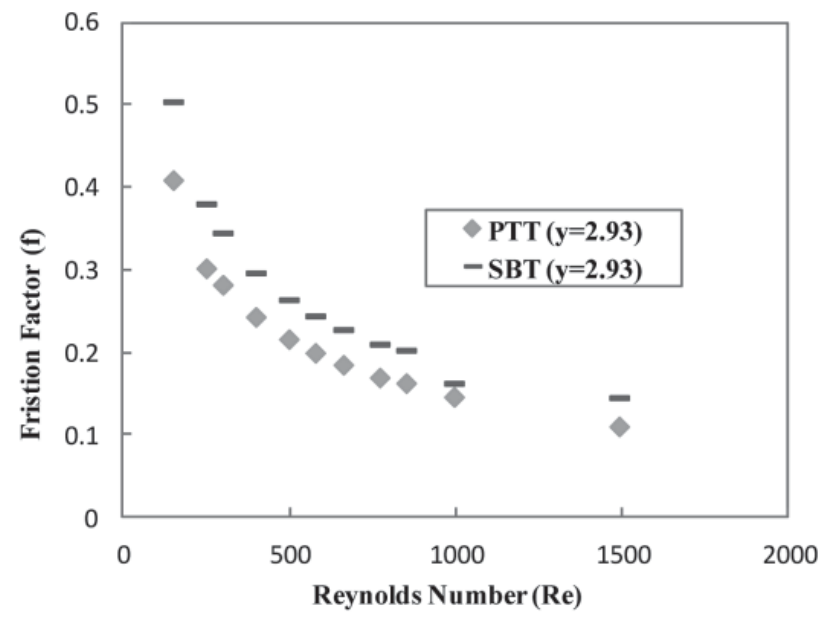

FIGURE 8. Simulated Friction Factor for PTT and SBT

\section{CONCLUSION}

CFD simulation for the heat transfer augmentation in a circular tube inserted by slant baffled twisted tape insert (SBT) with a twisted ratio $y=2.93$ and baffle angle $30^{\circ}$ has been simulated using FLUENT version 6.2.3.26. The data obtained by simulation are matching well with the literature value for plain tube for validation with the discrepancy of less than $\pm 8 \%$ for the Nusselt number and $\pm 6.25 \%$ for friction factor. The simulated results for the tube fitted with plain twisted tape inserts with twist ratios, $y$ of 2.93 and 3.91 was also conducted for comparison. The results show that the slant baffled twisted tape (SBT) insert offered further enhancement in heat transfer with significant increases in friction factor than those of plain twisted tape.

\section{ACKNOWLEDGEMENT}

The authors would like to thank University Kebangsaan Malaysia and MOHE for financial support (FRGS/1/2013/ TK07/UKM/01/1).

\section{REFERENCES}

Guo, J. Fan, A. Zhang, X. \& Liu, W. 2011. Numerical study on heat transfer and friction factor characteristics of laminar flow in a circular tube fitted with center cleared twisted tape. International Journal of Thermal Sciences 50(7): 1263-1270.

Ibrahim, E. Z. 2011. Augmentation of laminar flow and heat transfer in flat tubes by means of helical screw-tape inserts. Energy Conversion and Management 52(1): 250-257.

Jaisankar, S. Radhakrishnan, T. K. \& Sheeba, K. N. 2009. Experimental studies on heat transfer and friction factor characteristics of thermosyphon solar water heater system fitted with spacer at the trailing edge of twisted tapes. Applied Thermal Engineering. 29(5-6): 1224-1231. 
Pathipakka, G. \& Sivashanmugam, P. 2010. Heat transfer behavior of nanofluids in a uniformly heated circular tube fitted with helical inserts in laminar flow. Superlattices and Microstructures. 47(2): 349-360.

Salman, S. D. Kadhum, A. A. H. Takriff, M. S. \& Mohamad, A. B. 2013. CFD simulation of heat transfer and friction factor augmentation in a circular tube fitted with ellipticcut twisted tape inserts. Mathematical Problems in Engineering, vol. 2013, Article ID 163839, 7 pages.

Salman, S.D. Kadhum, A. A. H. Takriff, M. S. \& Mohamad, A. B. 2013. Numerical Investigation of Heat transfer and friction factor characteristics in a circular tube fitted with V-cut twisted tape inserts. The Scientific World Journal, vol. 2013, Article ID 492762, 8 pages.

Shabanian, S. R. Rahimi, M. Shahhosseini, M. \& Alsairafi, A. A. 2011. CFD and experimental studies on heat transfer enhancement in an air cooler equipped with different tube inserts. International Communications in Heat and Mass Transfer 38(3): 383-390.

Sieder, E. N. \& Tate, G. E. 1936. Heat transfer and pressure drop of liquids in tubes. Industrial and Engineering Chemistry Research 28(12): 1429-1435.

Ujhidy, A., Nemeth, J. \& Szepvolgyi, J. 2003. Fluid flow in tubes with helical elements. Chemical Engineering and Processing 42(1): 1-7.
Wongcharee, K. \& Eiamsa-ard S. 2011. Friction and heat transfer characteristics of laminar swirl flow through the round tubes inserted with alternate clockwise and counter-clockwise twisted-tapes. International Communications in Heat and Mass Transfer 38(3): 348-352.

Sami D. Salman, Abdul Amir H. Kadhum, Mohd S. Takriff \& Abu Bakar Mohamad

Jabatan Kejuruteraan Kimia dan Proses

Fakulti Kejuruteraan dan Alam Bina

Universiti Kebangsaan Malaysia

43600 UKM Bangi, Selangor D.E.

Malaysia

Sami D. Salman

Al-Khawarizmi Kolej Kejuruteraan

Universiti Baghdad, Iraq 47024

*Corresponding author; email: sami.albayati@gmail.com

Received date: $24^{\text {th }}$ April 2014

Accepted date: $14^{\text {th }}$ August 2014 
